\title{
VIDEOSTUDIE V MUZEJNĚPEDAGOGICKÉM VÝZKUMU: PŘíPADOVÁ STUDIE
}

VERONIKA KOLAŘÍKOVÁ

\section{ABSTRAKT/ABSTRACT:}

Cílem textu je představit videostudii jako užitečný metodologický nástroj využitelný $\mathrm{v}$ oblasti analýzy muzejní edukace. Videostudie se dnes stále častěji objevuje ve výzkumech edukační reality. Její prrínos však není omezen pouze na výzkum školní výuky, ale použít ji lze také v muzejním prostředí. Analýza muzejně edukačních programů se přitom nemusí zabývat jen formami výuky, jejím obsahem a dalšími klasicky zkoumanými edukačními jevy. Jak ukazuje předkládaná př́padová studie, videodata mohou být součástí analýz rozmanitých muzejních fenoménů. Těmi mohou být aktuální muzejní trendy, jako např. orientace muzea na každodenní život návštěvníků, nebo se výzkumná pozornost může obracet $\mathrm{k}$ analýze role muzejního prostředí v edukaci apod.

\section{Video study in museum} education research: a case study

The aim of this study is to introduce video study as a useful methodological tool in the museum education analysis. Video study is nowadays increasingly used to investigate the educational reality. However, its contribution is not limited to research into school education; it can be also employed in the museum environment. The analysis of museums' educational programmes does not only deal with the forms of teaching, its content and other typical educational phenomena. As this case study shows, video data can be also part of the analysis of other museum phenomena such as current museum trends (for example, the focus on everyday life of the visitors). Similarly, attention can be devoted to the analysis of the role of the museum environment in education and the like.

\section{KLÍČOVÁ SLOVA/KEYWORDS:}

muzeum - muzejní edukace videostudie - SWOT analýza otevřené kódování

museum - museum education - video study - SWOT analysis - open coding

Edukační programy muzeí jsou dnes na vzestupu. Zajímat by nás ale neměla pouze jejich četnost, nýbrž i jejich kvalita. S výzkumy zabývajícími se povahou edukačních programů muzea mohou pomoci videostudie. Ty se postupně stávají součástí reality nejrůznějších pedagogických výzkumů a potenciál jejich přínosu tkví také ve výzkumu muzejněpedagogickém. Videostudie může přinést podstatné informace nejen muzejním výzkumníkům, ale také muzejním pedagogům a dalším zaměstnancům muzea, kterým je schopna poskytnout zpětnou vazbu týkající se nejrůznějších aspektů probíhající edukace. Díky tomu může být videostudie součástí akčního výzkumu, jehož cílem je nejen hlubší pochopení zkoumané reality, ale především snaha o zkvalitnění zkoumaného jevu, tedy např̀. edukačního procesu.
Cílem textu je představit problematiku videostudií a nastínit jejich potenciální přínos právě v muzejně edukačním výzkumu. Tohoto cíle bude dosaženo pomocí teoretického vhledu do dané problematiky a následné prezentace výzkumné př́ípadové studie. Ta slouží jako konkrétní ukázka způsobu využití a zpracování videostudie zabývající se analýzou edukačního programu Slezského zemského muzea v Opavě.

\section{VIDEOSTUDIE}

Pojem videostudie „označuje výzkumy, $v$ nichž je využito videa jako prostředku sběru a analýzy dat, popř. jako média prezentace výzkumných zjištění."1 Videostudie představuje „komplexní metodologický postup, v jehož rámci se může uplatnit řada různých strategiú, metod či technik sběru a analýzy videodat - tj. audiovizuálních dat zakotvených $v$ bohatých kontextech. Výzkumný potenciál videostudie spočivá $v$ tom, že komplexní jevy a děje zachycené na videozáznamu jsou přistupné analýzám, které se mohou ex-post zaměrovat na různé aspekty zkoumané problematiky.“2 Videostudie stojí na pozorování, které přináší nové informace o sledovaném fenoménu. Jádrem videostudie jsou videodata a jejich analýza. Videozáznam přitom umožňuje pozorovat zkoumanou realitu zprostředkovaně a opakovaně se k ní vracet.

1 Videostudie v pedagogickém výzkumu. Brno: Paido, 2011, s. 9.

2 Videostudie v pedagogickém výzkumu. Brno: Paido, 2011, s. 16. 
Samotná analýza dat se obvykle zakládá na analýze přepisů videodat, které nejčastěji tvoří transkripty verbálních či neverbálních projevů aktérů edukace. Výhodou videodat je podle Najvara, Najvarové, Janíka a Šebestové ${ }^{3}$ jejich trvanlivost, spolehlivost, zachování komplexnosti zkoumané reality, informační bohatost a možnost zkoumat díky jejich povaze komplexní procesy, zachytit a analyzovat simultánnost nebo kódovat stejné situace $\mathrm{z}$ více perspektiv, díky videodatům je také možné realizovat výzkum jako cyklický analytický proces a pro výzkumníka je snadnější ve výzkumu navzájem propojovat kvantitativní i kvalitativní př́stupy. Na druhou stranu autoři upozorňují také na problémy, které s videodaty souvisejí. Jde např. o fakt, že nahrávání videa může jistým způsobem pozorovanou realitu narušovat, jejich pořizování je časově a technicky náročné atd.

V pedagogické rovině bývají videostudie využívány především ke zkoumání edukační reality. Na propagaci analýzy videozáznamu jako prostředku výzkumu výuky se výrazně podílely mezinárodně srovnávací studie TIMMS, ${ }^{4}$ které tuto metodologii začaly používat v letech 1995 a 1999 při analýze výukových procesů v matematice a přírodních vědách. Nejčastěji se videostudie související s edukačními procesy zaměřují na výzkum výuky, který se obvykle týká jejich forem, fází a prostředků. Pomocí videostudií je ale možné zkoumat také výukové metody a další edukační

\footnotetext{
3 Videostudie v pedagogickém výzkumu. Brno: Paido, 2011, s. 31-38.

4 Srov. JANíKOVÁ, Marcela. Interakce a komunikace ve výuce: výzkumné oblasti, př́stupy a metody. In JANÍKOVÁ, Marcela, Kateřina VLČKOVÁ a kol. Výzkum výuky: tematické oblasti, výzkumné přistupy a metody. Brno: Paido, 2009, s. 51; Videostudie v pedagogickém výzkumu. Brno: Paido, 2011, s. 9.
}

jevy. Podle Janíkové ${ }^{5}$ mohou být videostudie vhodné také „ke zkoumání interakce a komunikace ve výuce." Stejně jako je možné použít videostudii $\mathrm{k}$ analýze edukačního procesu probíhajícího ve škole, je možné tuto výzkumnou formu využít $\mathrm{v}$ prostředí muzea $\mathrm{k}$ analýze muzejně edukačních aktivit a jevů. V rámci analýzy edukačních programů muzea se přitom nemusíme zaměřovat pouze na obsahovou či didaktickou stránku edukace, ale pozornost můžeme věnovat také tomu, jakou roli v edukaci hraje prostředí muzea, nakolik edukace odpovídá moderním požadavkům kladeným na muzea, jakými může být např. propojení muzea a jeho aktivit s každodenním životem návštěvníků apod. Sledovat lze také to, jak edukační program pracuje s expozicí a exponáty muzea a tedy i to, jakou roli hraje muzealita v odehrávajícím se edukačním procesu, nebo nakolik je edukační proces propojen se sociální rolí muzea apod.

At̛ už je téma i cíl videostudie jakýkoli, postup realizace videostudie ${ }^{6}$ bývá obdobný a výzkumník by měl být s jejím průběhem dobře obeznámen. Součástí plánovaného výzkumu by vždy měla být přípravná fáze, ve které výzkumník zpracovává teoretická východiska i časový plán, stanovuje výzkumný vzorek a zajištuje technické zázemí výzkumu. Poté následuje fáze pořízení videozáznamu, před jehož započetím se musí výzkumník rozhodnout, kolik kamer k záznamu použije a koho a jak budou kamery zaznamenávat (učitel, žáci), zda budou kamery pohyblivé či statické, kde budou umístěny apod. Spolu s videozáznamem

\footnotetext{
5 JANÍKOVÁ, Marcela. Interakce a komunikace ve výuce: výzkumné oblasti, př́stupy a metody. In JANÍKOVÁ, Marcela, Kateřina VLČKOVÁ a kol. Výzkum výuky: tematické oblasti, výzkumné př́stupy a metody. Brno: Paido, 2009, s. 51. 6 Videostudie v pedagogickém výzkumu. Brno: Paido, 2011, s. 39-44.
}

mohou být získávána kontextová data a to např. skrze dotazníky, rozhovory apod. Následně bývají pořízeny kompletní transkripty videozáznamů. Třetí fází je fáze kódování dat, ve které se často uplatňují kategoriální systémy a posuzovací škály. „S využitím kategoriálních systémů lze identifikovat výskyt (event sampling) a délku trvání (time sampling) jevů. [...] S využitím posuzovacích škál lze hodnotit míru či intenzitu (popř. kvalitu) pozorovaných jevü."7 Techniky kódováni dat ale mohou být i jiné. Získané kódy jsou následně ve čtvrté fázi podrobeny analýze a vyhodnocení dat.

\section{ANALÝZA EDUKAČNÍHO PROGRAMU}

Předkládaná případová studie slouží jako ukázka toho, jak je možné videostudii v muzeu provádět a jak ji využít v kontextu edukačních aktivit muzea.

Cílem videostudie bylo zjistit, jak je $v$ analyzovaném muzejně edukačním programu nakládáno s prostředím muzea. $\mathrm{Tj}$. nakolik prostředí muzea a jeho fyzické prostory včetně vybavení ovlivňují muzejní edukaci a jaká specifika s sebou oproti běžné edukaci ve škole muzejní prostředí přináší. Myšlenka důležitosti muzejního prostředí není nikterak nová. Tuto problematiku výstižně shrnul už Stránský, ${ }^{8}$ když napsal, že „muzeum je prostorová záležitost. Potřebuje odpovídající prostor, prostředí a vybavení. A to nejen ve vztahu $k$ vlastnímu poslání a úloze, ale také ve vztahu k jeho pracovníkům a uživatelům."

Dnes je problematika muzejního prostředí dávána do spojitosti s aktuálními požadavky týkajícími se ideálu otevřeného (všem přístupného) a inkluzivního muzea

\footnotetext{
7 Videostudie v pedagogickém výzkumu. Brno: Paido, 2011, s. 42-43.

8 STRÁNSKÝ, Zbyněk Z. Archeologie a muzeologie. Brno: Masarykova univerzita, 2005, s. 132
} 
(tj. muzea překonávajícího nejen fyzické, ale i kulturní, sociální a další bariéry). ${ }^{9}$ Architektura muzea, jeho urbanistické umístění a samozřejmě i jeho vnitřní prostory, vybavení a způsob prezentace, jsou odborníky neustále zvažovány a projevuje se snaha o vytvoření souladu mezi muzejním prostředím a jeho funkcí směřující $\mathrm{k}$ široké veřejnosti a její v muzeu prožívané zkušenosti, která je mimo jiné právě i prostředím muzea ovlivňována. Prostředí muzea ovlivňuje proces edukace jak z hlediska edukačního obsahu (vliv tématu expozice, typu muzea, vliv povahy a množství exponátů stejně jako i způsob jejich prezentace apod.), tak z hlediska metod a forem práce (které jsou odlišné od těch školních a které zdůrazňují aktivní zapojení se návštěvníků do procesu edukace a využití exponátů, kterými škola nedisponuje).

Spolu s prostředím muzea se výzkum zajímal o propojenost muzejní edukace s každodenním životem návštěvníků, což je požadavek, který se dnes dostává stále více do popředí činnosti muzea spolu s tím, jak roste důraz kladený na sociální poslání muzea. Současná muzea se snaží stát centrem kulturního dění místních komunit, ${ }^{10}$ nebot právě jejich členové tvoří přirozené prostředí muzea situovaného v konkrétní lokalitě, její kultuře a sociální realitě spjaté se specifickým životním stylem i životními problémy.

9 MACLEOD, Suzanne (ed.). Reshaping Museum Space: Architecture, Design, Exhibitions. London, New York: Routledge, 2005

10 Srov. WORTS, Douglas. Extending the Frame: Forging a New Partnership with the Public. In PEARCE, Susan. Art in Museums. London: The Athlone Press, 1995, s. 164-191; FALK, John H., Lynn D. DIERKING and Marianna ADAMS. Living in a Learning Society: Museums and Free-choice Learning. In MACDONALD, Sharon. A Companion to Museum Studies. Malden, MA: Blackwell

Publishing, 2006, s. 323-339.

\subsection{Představení analyzovaného programu}

Analyzovaný muzejně edukační program Argumentace byl součástí dlouhodobého edukačního cyklu Filozofie pro děti v muzeu, který se odehrával ve spolupráci muzejní pedagožky (dále jen „pedagožky“) s konkrétní školní tř́idou v období od října 2016 do dubna 2017. Cyklus byl složen $\mathrm{z}$ deseti edukačních programů, ${ }^{11}$ orientujících se na rozvoj kritického myšlení žáků. Za tímto účelem pedagožka využívala tzv. RWCT metody, ${ }^{12}$ které „na základě práce s texty a jazykem umožňují žákům systematicky a promyšleně prozkoumávat cíleně zvolená témata a vytvářet si vlastni hypotézy a názory."13 Jako takové mohou být tyto metody pro práci v muzeu vhodné. ${ }^{14}$ Umožňují totiž propojit požadavek „hands on“, který se soustředí na vlastní činnost návštěvníků v muzeu a na manipulaci s předměty s požadavkem „brains on“, tedy se snahou zapojit do činnosti také proces myšlení.

Analyzovaný program se odehrával $\mathrm{v}$ prostředí společenskovědní expozice muzea pojmenované Encyklopedie Slezska. Expozice se týká dějin, kultury a obyvatelstva této lokality a je řazena tak, aby asociovala encyklopedii Slezska, tj. je organizována jako slovníček pro Slezsko typických pojmů - hesel, ke

\footnotetext{
11 Edukační programy cyklu byly: Seznámení s Filozofií pro děti; Říkám, co si myslím; Křehké cestovatelky; Argumentace; Svoboda/bezpečnost; Já - od jména k identitě; O smyslu a štěstí; Spravedlnost; Dar; Reflexe celého cyklu Filozofie pro děti v muzeu.

12 RWCT metody (Reading and Writing for Critical Thinking $=$ čtením a psaním ke kritickému myšlení)

13 DOLEJŠKOVÁ, Petra. Tajemství muzea pedagogicky konstruktivismus a postupy programu RWCT v muzejně-pedagogické praxi určené žákům základních škol. Muzeum: muzejní a vlastivědná práce, 2011, roč. 49, č. 2, s. 25. 14 DOLEJŠKOVÁ, Petra. Tajemství muzea pedagogicky konstruktivismus a postupy programu RWCT v muzejně-pedagogické praxi určené žákům základních škol. Muzeum: muzejní a vlastivědná práce, 2011, roč. 49, č. 2, s. 25.
}

kterým vždy náleží část expozice. Expozice má návštěvníkům přiblížit „kaleidoskopickým, výběrovým, tematickým způsobem české Slezsko od pravěku do 20. století s nezbytnými presahy za tuto časovou hranici smèrem $k$ dnešku. "15 Takto řazená expozice je jistě zajímavá. Pro návštěvníky, především ty dětské, však může být problematická, nebot jim nenabízí jednoduchý explicitně viditelný chronologický narativ. $\mathrm{Na}$ druhou stranu expozice umožňuje pedagožce pracovat s potřebnými hesly samostatně, díky čemuž se jí otevírá široká škála témat k rozpracování.

Analyzovaný program využíval muzejních hesel „město“ a „venkov“. Hlavními cíli programu, které pedagožka definovala, přitom bylo nejen věnovat se tématu života ve městě a na vesnici, ale také rozvíjet komunikační a argumentační schopnosti žáků, vzbudit zájem dětí o práci ve skupině a vést je k uvědomění si, vyjádření a obhájení svých postojů, názorů a hodnot a to vše s ohledem na věkové zvláštnosti dané návštěvnické skupiny.

Edukační program trval 70 minut. Návštěvnická skupina byla složena ze 17 žáků 4. a 5. ročníku vesnické školy nacházející se v blízkosti Opavy a jejich třídního učitele. Žáci obou ročníků jsou vzděláváni dohromady v rámci jedné věkově smíšené tř́ídy. V době výzkumu žáci navštěvovali školu prvním rokem, předtím většina $\mathrm{z}$ nich chodila do školy v Opavě, odkud také většina pochází. Žáci se tak každodenně potýkali s realitou (kterou identifikovala pedagožka po rozhovoru s třídním učitelem i po delší době spolupráce s žáky

15 Slezské zemské muzeum [online]. [cit. 2017-01-22]. Dostupný z www: <www.szm. cz/clanek/2538/expozicni-arealy/historickavystavni-budova-opava/expozice/encyklopedieslezska.html>. 
samotnými), v níž se jako městské děti dostávaly do kontaktu s lidmi žijícími na vesnici, přičemž místní žáky často vnímali jako př́slušníky cizí městské skupiny. Ve vzájemných vztazích tak bylo možné sledovat v sociální realitě se běžně vyskytující tendenci lidí vytvářet si představy o členech skupiny prostřednictvím tvorby kategorii „oni“, tj. ti jiní, nenáležející k naší skupině (v tomto případě „ti městští"), která bývá dávána do kontrastu s kategorií vlastní skupiny „my“ (tj. „venkovští“). Žáci se proto nově museli vypořádávat s otázkou vlastní identity odvíjející se od jejich městského či ne-městského původu, s potřebou začlenit se do nového společenství i s procesem poznávání odlišných způsobů života.

Expozici muzea už žáci znali z předchozích lekcí, takže $\mathrm{v}$ rámci programu nebylo nutné žáky s prostředím muzea nově seznamovat. Edukační aktivity dodržovaly typický sled fází muzejně edukačního programu, který doporučuje např. Šobáňová, ${ }^{16}$ podle které by měl edukační program začínat evokací, tedy motivací návštěvníků $\mathrm{k}$ procesu učení a zjištění jejich dosavadních znalostí. Dále by měly následovat samotné aktivity vedoucí $\mathrm{k}$ osvojení si edukačního obsahu. Se závěrem se pojí reflexe, tedy zjištění, co se návštěvníci v muzeu naučili, jak se v něm cítili a jak to mohou získanou zkušenost ve svém životě zužitkovat.

Na začátku programu došlo k rekapitulaci pravidel chování, které si žáci společně s pedagožkou stanovovali v první edukační lekci. Po fázi uvítání a evokace, které dohromady trvaly 5 minut, došlo k první aktivitě trvající 12 minut. $V$ rámci aktivity si měli

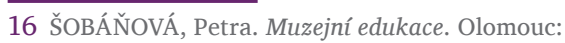
Univerzita Palackého v Olomouci, 2012, s. $124-125$. žáci vybrat z nabízených předmětů (kouzelný ubrousek „prostři se“, létající koberec a mluvící kniha) předmět, který by chtěli vlastnit. Až poté dostali $\mathrm{k}$ předmětům bližší informace, díky kterým mohli svou volbu předmětu dodatečně změnit. Následně měli vysvětlit, proč se rozhodli pro danou věc a svou volbu obhájit. Aktivita sloužila $\mathrm{k}$ rozehřátí a navození do procesu zvažování informací, rozhodování se mezi nabízenými alternativami a obhajování svých voleb.

V další aktivitě trvající 25 minut dostali žáci za úkol rozestoupit se na kříži osy podle toho, jakou preferenci přikládali výrazům z dvojice slov umístěných na levé a pravé straně osy, kdy střed osy znázorňoval neutrální postoj. Aktivita směřovala $k$ hlubší reflexi problematiky města a venkova, ve svém průběhu ale otevírala i jiná diskutabilní témata. Napřs. když žáci volili mezi chlebem a čokoládou sami nastiňovali témata výživy, dostupnosti potravin a s tím pojící se problematiku chudoby. Dalšími dvojicemi slov byly pojmy neviditelnost - umět létat, člověk kočka a překvapení - jistota.

Hlavní pojmovou binaritou na ose, od které se uskutečňovala nejdéle trvající diskuze, pak byla dvojice město - venkov.

Klíčovou aktivitou programu byla práce ve dvojicích rozdělených pomocí losu, ve kterých žáci diskutovali výhody a nevýhody bydlení bud' ve městě, nebo na venkově, přičemž příslušnost k venkovu či městu si žáci vytáhli spolu s losem. Jejich úkolem bylo najít argumenty pro danou variantu, aniž by nutně sami byli s touto variantou osobně ztotožněni. Cílem bylo naučit se vnímat jevy komplexně, hlouběji se nad nimi zamýšlet a hledat klady i zápory ve věcech, které se mohou rozcházet s vlastními postoji. Po hledání argumentů ve dvojicích se děti vrátily na koberec, kde si vyměnily své role a kolektivně své argumenty diskutovaly. Při komunikaci používaly kartičky s větami typu „Rád(a) bych navázal(a) na...", „Souhlasím protože...“, „Mám na to jiný názor než..." apod., které jim pomáhaly smysluplně se vyjádřit a zároveň jim pomocí své formulace názorně ukazovaly, že i nesouhlas s se dá vyjádřit slušně a s respektem. Aktivita trvala 20 minut.

Po každé z aktivit následovalo její shrnutí a vysvětlení jejího cíle. Program byl zakončen závěrečnou reflexí v rozsahu 8 minut. Cílem reflexe bylo shrnout $v$ muzeu nabytou zkušenost. Reflexe se účastnil i třídní učitel, který se průběžně zapojoval do všech aktivit. Se svými žáky tak neztrácel kontakt a byl součástí jejich muzejní zkušenosti.

\subsection{Metodologie výzkumu}

Studie vychází z kvalitativní výzkumné metodologie. Data pro analýzu byla získána prostř̌ednictvím pozorování edukačního programu, který byl v celém svém rozsahu nahrán na videozáznam a bezprostředně po skončení programu opatřen terénními poznámkami. Záznam byl nahráván na jednu kameru, která byla $\mathrm{v}$ pohybu podle toho, jak se skupinka žákủ s pedagožkou přemistovala $\mathrm{v}$ rámci prostoru a který zaznamenával aktivitu pedagožky i aktivitu žáků. Následně byl udělán přepis záznamu sloužící $\mathrm{k}$ zevrubnější kvalitativní analýze, při které byl používán nejen přepis, ale opakovaně se vracelo také $\mathrm{k}$ pořízené nahrávce. Pozornost při analýze přitom byla věnována jak chování a jednání pedagožky tak samotných žáků. Data byla získána také prostřednictvím polostrukturovaného rozhovoru s pedagožkou, který se uskutečnil po skončení programu. Získaná data byla podrobena otevřenému 
kódování, které Zounek a Šed’ová ${ }^{17}$ popisují jako proces segmentování textu (analyzovaného přepisu a rozhovoru) na mikroepizody ve snaze rozklíčovat jejich významy a označit je náležitými kódy. Kódy jsou následně kategorizovány, díky čemuž může výzkumník odhalit základní témata vztahující se ke zkoumanému problému. Celou analytickou práci završuje SWOT analýza, která si kladla za cíl identifikovat silné a slabé stránky programu.

Studie si stanovila následující hlavní a vedlejší výzkumné otázky:

\section{Hlavní výzkumné otázky}

- Jakou roli hraje $\mathrm{v}$ rámci edukační reality analyzovaného edukačního programu prostředí muzea, resp. jeho prostory a vybavení včetně samotných exponátů expozice?

- Jakými způsoby je analyzovaný edukační program a jeho téma navázáno na každodenní život návštěvníků?

\section{Vedlejší výzkumné otázky}

- Jak byly prostory muzea $\mathrm{v}$ rámci edukačního programu využívány?

- Jaké benefity prostor muzea oproti běžné školní tř̌ídě účastníkům edukačního programu nabízel a naopak jaká rizika se $\mathrm{s}$ edukací $\mathrm{v}$ tomto prostředí pojila?

- Čím vším se projevoval vztah tématu edukačního programu ke každodenní realitě jeho účastníků?

\subsection{Analýza dat}

Na základě otevřeného kódování došla analýza hledající odpovědi na výzkumné otázky $\mathrm{k}$ několika

17 ZOUNEK, Jiří a Klára ŠEĎOVÁ. Jak zkoumat ict v každodenní práci učitele aneb videostudie jako kvalitativní metoda. Orbis scholae, 2008, roč. 2 , č. 1 , s. 144 . výzkumným kategoriím, které se dominantně orientovaly kolem tématu muzejního prostředí a vztahu muzejní edukace ke každodennímu životu a zkušenosti návštěvníků. Výzkumná zjištění jsou v textu strukturována právě s ohledem na tato dvě výzkumná témata a s nimi související výzkumné kategorie, které jsou postupně představovány. Jednotlivé kategorie jsou v textu popsány a opatřeny ukázkami pocházejícími z rozhovoru s pedagožkou (analyticky významné části jsou zvýrazněny podtržením textu), ukázkami z edukačního programu (ukázky z komunikace odehrávající se $\mathrm{v}$ rámci edukačního programu) a popisem situací a dějů zachycených $\mathrm{v}$ rámci videostudie. Součástí analýzy dat je také SWOT analýza.

\subsubsection{Výzkumné téma: Prostředí muzea}

Historická výstavní budova Slezského zemského muzea se nachází $\mathrm{v}$ prostředí parku $\mathrm{v}$ centru města s rozvinutou sítí škol, v bezprostřední blízkosti autobusové a vlakové zastávky, což návštěvníkům ulehčuje dopravu do muzea. Neorenesanční budova muzea svým vzhledem asociuje pocit historické hodnoty, důležitosti a velkoleposti. Tři oddíly stálé expozice (Příroda Slezska, Encyklopedie Slezska a Historie Slezska) se rozprostírají ve třech patrech muzea, jehož součástí je také amfiteátr s pokladnou, schodištěm a uzamykatelnými skř́iňkami.

Pro muzejního pedagoga prostředí muzea skýtá řadu výhod, ale i rizik, které musí ve své praxi řešit. Typicky jde o nutnost chránit muzejní sbírky před poškozením, brát ohled na další návštěvníky muzea, nebo poskytovat návštěvníkům prostor pro odpočinek. Analyzovaný program se odehrával v době, kdy v muzeu nebyly přítomni další návštěvníci, takže ke kontaktu žáků s^nimi nedocházelo. Ostatní specifika pojící se s muzejním prostředím, jako je osvětlení prostoru, pohyb po místnosti apod. ale musela pedagožka při své práci zohlednit.

\section{- Kategorie: Pravidla chování a manipulace $s$ exponáty}

Na začátek programu pedagožka s žáky zrekapitulovala pravidla chování v muzeu, které si společně vytyčily na počátku edukačního cyklu. Pravidla si žáci sepsali na arch papíru, který pedagožka do programu přinesla. Pravidla chování v muzeu jsou specifická a otázka ochrany muzeálií byla pro žáky novým tématem. Stanovení pravidel pomohlo žákům pochopit specifičnost muzejního prostředí. To je vnímáno jako kulturní prostředí, kterého si společnost váží, a proto stanovuje pravidla chování v něm vyžadovaná (v muzeu se neběhá, nekřičí, nesahá na exponáty apod.). Pomocí definování pravidel nemožnosti manipulace $s$ exponáty se žákům objasňoval význam a hodnota exponátů a s nimi spojené muzeality.

Z rozhovoru vyplynulo, že pedagožka kladla důraz na potřebu chránit vystavené originály. Zároveň si ale pedagožka uvědomovala edukační význam interaktivity a manipulace návštěvníků s předměty, což je důvodem toho, proč jsou v muzeu vyráběny různé repliky nebo používány zástupné předměty. $\mathrm{V}$ analyzovaném programu k využívání replik nedocházelo a hmotné věci byly využívány jen při první aktivitě. Spíše než manipulovat $s$ předměty se žáci učili manipulovat s myšlenkami, přičemž jejich názory mohly být demonstrovány pohybem vlastního tělo a situováním se $\mathrm{v}$ prostoru na škále osy. 
Přestože se muzejní edukace pojila s určitými zákazy, neznamená to, že by muzeum nebylo přátelským místem. Naopak i k tomu stanovení společných pravidel chování směřovalo. Mělo totiž pomoci vytvořit $\mathrm{v}$ muzeu pracující skupince žáků takovou atmosféru, v níž by se cítili všichni dobře. $O$ tom svědčí samotný název pravidel, kdy arch papíru s nimi byl nadepsán sloganem „Aby se nám tady dobře pracovalo.“ Žáci se shodli na tom, že se budou snažit udržet „pohodu, príijemnou a klidnou atmosféru; nebudou si skákat si do řeči a prekřrikovat se; budou se navzájem respektovat." K^pravidlům se pedagožka $v$ průběhu programu vracela. Např. ve chvíli, kdy dva žáci vyrušovali, legitimizovala jim určené napomenutí požadavkem dodržování právě toho, co si sami žáci určili za důležité. Tím se snažila posílit vnitřní sebekontrolu žáků a rozvíjet jejich morální cítění.

„V první lekci sme si řekli, jaká pravidla chování tady budeme dodržovat. Že je tady trochu speciální režim...že? A zároveň sme si říkali, jak se budeme chovat abychom se tady cítili dobře, jak chceme aby se k nám chovali ostatní. Co konkrétně sme si teda slíbili, kdo mi to zopakuje?" (výrok pedagožky v edukačním programu)

„Je to rušivé a je to nepř́íjemné pro ostatní. A to pravidlo, že se budeme chovat tak at' to neruší ostatní a cítíme se tu dobře, to ste si přece zvolili sami." (výrok pedagožky v edukačním programu)

\section{- Kategorie: Rušivé elementy}

Edukační program se konal v jedné velké místnosti muzea, ve které se nachází několik tematických hesel expozice, včetně hesel města a venkova. Expozice je zde členěna na několik částí a tvoří malá zákoutí. Uprostřed místnosti se nachází projektor promítající na strop záznam plynoucích mraků. Projekci ponechala pedagožka zapnutou, aby podpořila emoční prožívání žáků $\mathrm{s}$ vědomím, že možná bude muset řešit jeho rozptylující efekt, který ale neměl být podle jejich dosavadních zkušeností s danou třídou velký. Rušivým prvkem se projektor nakonec stal jen pro pár žáků, kteří $\mathrm{k}$ němu měli tendenci odbíhat a zkoumat jej. Jednalo se obvykle o tři žáky, kteří byli v třídním kolektivu noví a podle pedagožky do té doby neměli s RWCT metodami zkušenosti a proto na ně projektor působil rušivěji než na ostatní. Situace demonstruje důležitost dostatečné informovanosti muzejního pedagoga o návštěvnické skupině a jejich specificích a potřebách, které je potřeba při edukaci zohlednit.

\section{„Tam přibylo několik nových dětí} a myslím si, že to bylo docela dobře i vidět, protože ta skupina co pracovala celou dobu a fungovala, tak to je právě identický vzorek těch kteři už pracujou takhle dlouho. Ty dèti, které tam došly později nebyly takhle zvyklé pracovat, tak tèm to tolik nevyhovuje... nejsou na to tolik zvyklí.“ (rozhovor s pedagožkou)

Pedagožka manipulovala také s osvětlením, kdy volila střední intenzitu světla tak, aby $\mathrm{v}$ místnosti nebyla uspávající tma, ani př́liš ostré světlo. Dále pedagožka vypnula hlučnou klimatizaci, protože předpokládala, že nejen hluk ale i chlad by na děti pưsobily nepř́ijemně.

\section{- Kategorie: Vybavení muzea}

V rámci kategorie byla pozornost věnována tomu vybavení, které edukační práci v muzeu usnadňuje a které je vhodné v edukaci využívat. Jako důležitá součást materiálního vybavení se ukázaly být podložky na sezení, které žáci hojně využívali. Podložky jsou snadno přenositelné a umožňují nahradit obtížně manipulovatelné židle, kterých v expozici nebývá dostatek. Další materiální vybavení tvořil koberec a pomůcky (lepící páska $\mathrm{k}$ vytvoření osy, lístky s názvy dvojic pojmů, mezi kterými si žáci v jednotlivých aktivitách vybírali apod.).

„Pojd'me se ted’ přesunout zpátky ke koberci a vemte si ta kolesa, a až se usadíme, tak si řekneme co bude následovat." (výrok pedagožky v edukačním programu)

\section{- Kategorie: Využití potenciálu muzeality $v$ edukačním programu}

Muzea nabízí žákům nevšední edukační zážitek, který se odehrává $\mathrm{v}$ zajímavém a informačně bohatém prostředí. Žáci opouštějí prostředí běžné třídy a sezení v lavicích, což je dle pedagožky velice důležité, nebot samotný pohyb $\mathrm{v}$ expozici se podle ní podílí na edukaci a kultivaci návštěvníka. Pedagožka vnímá expozici jako prostor, kde jsou návštěvníci vystaveni muzealitě, která je prostřednictvím exponátů spontánně obklopuje. Proto $v$ edukačních programech nevyužívá speciální třídu, která je $\mathrm{v}$ muzeu k dispozici.

„No jinak $v$ muzeu je taky učebna s interaktivní tabulí. Ale nemám to moc ráda, nedává mi to smysl, nechápu proč ty děti by měly chodit místo svoji školní třídy do jiné tř́dy v muzeu. To mi príjde smysluplnějš́, že jsou mezi těmi exponáty, že to na ně nějak pưsobí, že to na ně nějak funguje. Že se mezi tím pohybujou. Věř́m tomu, že zafixujou nějaký predmět, že je něco zaujme. Už i jenom tím že si tam jdou sednout mezi ty vitríny, tak něco vnímají, i podvědomě." (rozhovor s pedagožkou)

Pedagožka v rozhovoru opakovaně zdůraznila edukační význam muzeality, ačkoli o muzealitě 
samotné explicitně nehovořila, respektive nepoužila tento pojem. Přestože se samotnými exponáty $\mathrm{v}$ konkrétním programu nepracovala. ${ }^{18}$ Více než na exponáty orientovala edukační proces na téma expozice. Upozadění práce s exponáty přitom definovala jako výjimečnou situaci a práci $\mathrm{s}$ exponáty se rozhodla alternovat $\mathrm{v}$ jednom $\mathrm{z}$ dalších programů. Chybějící práci s exponáty je přitom vhodné vnímat kontextuálně, tedy uvědomit si, že byl analyzovaný program součástí širšího celku, který jinak s exponáty pracoval. Upozadění muzeality bylo částečně zapříčiněno také faktorem nedostatku času, který pedagožka v kontextu s edukačními programy pocituje.

\section{„Jindy víc pracujís tou expozicí,} dneska to bylo spíš tak výjimečně. Chtěla jsem to pưvodně našroubovat víc, ale časově to nešlo, tak sem to rozdělila a nechám to do druhého programu. V něm se budeme bavit o městě a vesnici z`historického hlediska." (rozhovor s pedagožkou)

Konkrétní dopad v prostředí muzea př́tomné muzeality na žáky v^analyzovaném edukačním programu nebyl v centru výzkumné pozornosti a vyvozovat tak závěry o vlivu v prostorech muzea př́tomné muzeality na žáky není možné. Co už ale možné je, je říci, že se prostředí muzea ukázalo být významným činitelem podílejícím se na podobě probíhající edukace. Prostory, $v$ nichž edukace probíhala, totiž výrazně ovlivnily její podobu např́iklad tím, jaký poskytly prostor k pohybu žáků, nakolik umožnily vytvořit zónu pro relaxaci žáků apod.

18 Připomeňme, že s významem muzeality bylo pracováno pomocí stanovování pravidel chování. Jejich prostřednictvím bylo muzeum žákům prezentováno jako významná kulturní instituce pečující o kulturní hodnoty.

\section{- Kategorie: Využití prostoru v expozici}

Při edukaci byla využívána jedna velká místnost $\mathrm{z}$ expozice, která je rozčleněna do několika zón a uprostřed pomyslně dělena projektorem se sekvencí plynoucí oblohy. Pedagožka postupně využívala celého prostoru místnosti včetně zákoutí expozice. $\mathrm{V}$ expozici se žáci pohybovali bud’ všichni najednou (např. při přesunech mezi částmi expozice, ve kterých se uskutečňovaly konkrétní aktivity), nebo v menších skupinkách či dvojicích ve chvíli, kdy měli za úkol pracovat samostatně. Zároveň byl v části místnosti vytvořen relaxační prostor s kobercem, kam se mohli žáci v případě potřeby individuálně uchylovat. Tuto možnost někteří žáci reálně využívali. Prostor s kobercem byl využíván také ke skupinovým diskuzím.

„Pojdte si za mnou. Tady před náma je taková ćára, tady tohle. Vidíte to? Bude nám sloužit jako osa. Tady dám jeden nápis „umět létat“ a tady dám „být neviditelný.“ Tahle čára, to je prostředek, střed. Zkuste se postavit tam co byste chtěli...

Zkuste zaujmout nějaké místo. [...]

A ted'ka se vás budu ptát, proč ste se tam postavili..." (výrok pedagožky v edukačním programu)

„Rozmístěte se tady mezi těma vitrínama ty dvojice. Najděte si místo." (výrok pedagožky v edukačním programu)

\section{- Kategorie: Volný pohyb $\mathrm{v}$ prostoru}

Volností pohybu v muzeu se nemyslí jeho absolutní svévolnost, v rámci které by si žáci mohli chodit po muzeu zcela dle vlastní libovůle. To by nebylo žádoucí ani z hlediska ochrany muzejních sbírek, ani vzhledem $\mathrm{k}$ edukačním cílům. Pohyb v muzeu byl $\mathrm{v}$ rámci programu omezen na prostor konkrétní expozice.
Práce pedagožky s prostorem se ale neodrážela jen $\mathrm{v}$ předem naplánovaném výběru prostoru, $\mathrm{v}$ němž se edukace odehrávala, ale také spontánně při vykonávaných aktivitách, ve kterých pedagožka žáky v prostoru různě rozmistovala. Např. při úvodu pedagožka rozsadila dva bavením se vyrušující žáky. Tím využila specifickou strategii disciplinizace, která měla zajistit, aby se žáci navzájem nerušili a soustředili se.

Ačkoli volnost pohybu v muzeu nebyla absolutní, byl zde pohyb mnohem větší a volnější, než je tomu v běžné třídě. Pedagožka se řídila heslem „Ten koho to nebaví, nemusí rušit ty, které to baví." Neměla tím ale na mysli pouze snahu přimět děti $\mathrm{k}$ tomu, aby se navzájem poslouchali, když jeden z nich mluví a prokazovali si tak vzájemný respekt. Šlo také o dobrovolnost aktivit. Pokud žáci nechtěli nějakou z činností dělat, nemuseli a mohli se přemístit do relaxační části místnosti. Ani zde ale pohyb a dobrovolnost nebyli absolutní, protože se pedagožka snažila dětem vysvětlit, že opouštět aktivitu v jejím průběhu není slušné. Dobrovolnost účasti na aktivitách totiž neznamená, že aktivitu děti zanechávají ve chvíli, kdy si již vyzkoušely a řekly to své a nyní mají věnovat pozornost ostatním.

„Višs ostatní vás také poslouchali a proto to děláme, nejen abyste se naučili něco říct, ale taky ty ostatní poslouchat." (výrok pedagožky v edukačním programu)

\subsubsection{Výzkumné téma: Propojenost muzejní zkušenosti s každodenním životem návštěvníků}

Moderní muzea jsou úzce spjatá se sociální rolí, v rámci které se snaží orientovat na každodenní potřeby a zájmy svých návštěvníků. Tento aspekt se v analyzovaném 
programu projevoval především volbou tématu programu. Tím byla problematika života na venkově a na vesnici, která se úzce dotýkala aktuálně zaživané zkušenosti žáků. Kromě tématu programu se na každodennost žáků zaměřoval také cíl rozvoje komunikačních dovedností žáků, které jsou využitelné v jejich každodenní školní i mimoškolní praxi, snaha využívat v edukaci prvky konstruktivistických teorií učení, nebo úsilí podpořit dobré vztahy ve třídě, do které přistoupili noví žáci a kolektiv tak procházel proměnou skupinové dynamiky.

\section{- Kategorie: Téma „město a venkov"}

Téma vesnice a města bylo problematikou, kterou žáci aktuálně ve svém životě řešili a se kterým se každodenně potýkali při svém dojíždění do vesnické školy. Městský původ byl žákům připomínán okolím, které je vnímalo jako cizince pocházející z města. Žáci se proto museli do vesnického prostředí různými zpo̊soby začleňovat. Zároveň žáci na vlastní kůži poznávali, jaké je to žít nebo alespoň trávit určitý čas na vesnici a získávali tak vlastní zkušenost, kterou porovnávali s dosavadní zkušeností života ve městě.

„Bydlet ve městě a bydlet na vesnici to je téma, které je ted' hodně zajímá a pořád to ve škole $i$ mezi sebou řeší.“ (rozhovor s pedagožkou)

„No já si myslím že žít ve městě a žít na vesnici je teda jako rozdíl, fakt velkej. Třeba toho smogu tu není tolik a to jako je fakt dobrý.. To prostě ve městě ho máme furt." (výrok žákyně v edukačním programu)

Specifikem edukačního programu nebylo pouze to, že se dominantně neodvíjel od exponátů (spíše se snažil těžit $\mathrm{z}$ pozitiv muzejního prostředí jako takového), ale také fakt, že se více než na předávání nových informací pojících se $s$ problematikou života ve městě a na vesnici zaměřoval na práci s dosavadními informacemi, postoji a zkušenostmi žáků. Pedagožka směřovala činnost žáků k uvědomování si vlastních postojů a komunikaci o nich. I díky aktivitám pracujícími se stávajícími znalostmi žáků pak mohly být postoje žáků formovány.

„A dneska jsem to řešili fakt hodně, co si ty děti o tom myslí a jestli se třeba nemůžou na tu věc dívat ale i jinak." (rozhovor s pedagožkou)

„V čem se ještě liší ten život ve městě a na vesnici, to prece není jenom doprava a hodně aut ne? Co je ještě jiné?" (výrok pedagožky v edukačním programu)

\section{- Kategorie: Zapojování prvků konstruktivistických teorií učení}

V edukačním programu bylo možné pozorovat snahy o využití prvků konstruktivistických teorií učení. Ty se zrcadlily nejen ve snaze pedagožky využívat metody práce podporující rozvoj kritického myšlení (diskuze, argumentace, zvažování výhod a nevýhod konkrétních jevů apod.), ale také v orientaci programu na stávající každodenní zkušenost žáků.

Cílem programu bylo rozvíjet kritické myšlení žáků a to především za pomocí využívání RWCT metod, které se v rámci analyzovaného programu dominantně odvíjely od diskuze a záměrné argumentace.

V kontextu využívání konstruktivistických prvků učení je důležitý fakt, že se v edukačním programu neustále objevovala diskutabilní témata. Cílem aktivit s nimi spojených nebylo určit, který z pólu tématu je lepší nebo pravdivý, ale šlo o snahu podívat se na věc $\mathrm{z}$ více úhlů pohledu, vytvořit si na diskutovaný jev vlastní názor, nebo formulovat argument vycházející nejen z dosavadních postojù, ale také nových informací.

„Oni se vlastně s tím chlebem a s tou čokoládou dostali do takových věcí. Potom byly diskutabilní vlastně všechny ty tři věci, které na začátku dostali - ubrousek prostři se, létající koberec i mluvící kniha. To jako to mohly být vlastně danajské dary, jako velice nepř́ijemné. Člověk očekává od toho, že to teda je jenom pozitivní, ale ve chvíli kdy si uvědomí, že to s sebou nese i nějaká negativa nebo rizika, tak to si pak uvědomili, myslím si, že to jim pak docvaklo, že se na to musí dívat z více úhlů... Jo... Myslím, že se vždycky dostáváme v něčem na hranu..." (rozhovor s pedagožkou)

\section{- Kategorie: Naučení se komunikačních gest a jejich přenesení do prostředí školy}

Žáci se v muzeu naučili specifická komunikační gesta, která $\mathrm{v}$ analyzovaném programu při komunikaci používali (gesta rukou vyjadřující souhlas, nesouhlas apod.). Tato gesta následně začali žáci používat i v prostředí školy, kam je z muzea přenesli a začlenili do každodenní školní reality a to nejen své třídy, ale i tříd ostatních. Gesta třída zprostředkovala žákům $\mathrm{v}$ rámci diskuzí ve školním sněmu, kde se gesta nakonec stala běžnou součástí komunikace. Událost demonstruje, jak úzce může být muzejní zkušenost provázána s každodenním životem návštěvníků a jak se mohou znalosti a dovednosti nabyté $\mathrm{v}$ muzeu stát součástí jejich běžného dne.

„Já jsem jim tehdy rozdala nákresy takových gest, co se použivají $v$ diskuzi a oni je vlastně naučili celou školu a použivají to při školních sněmech...To byla taková ta gesta jak dělali $v$ těch diskuzích rukama-jakože souhlasí, potom 
když se to moc opakuje a tak." (rozhovor s pedagožkou)

\section{- Kategorie: Práce s třídním kolektivem}

V rámci aktivit žáci pracovali nejen samostatně (např. když měli zaujmout pozici na škále), ale také ve dvojicích, skupinkách a všichni dohromady při společných diskuzích. Žáci se učili předávat si slovo a navzájem se poslouchat i uvažovat nad argumenty ostatních. Pedagožka se snažila, aby se ke slovu dostal každý a aby nemluvili pouze někteří žáci. Za tímto účelem korigovala komunikaci, podněcovala žáky otázkami, dávala slovo vybraným žákům a svůj výběr zdůvodňovala pomocí výroků „ty jsi ještě nic neřekl (a)“, „ty máš k tomu také určitě co ř́ct", „chtěla bych slyšet každého z vás", nechávala vyjádřit se $\mathrm{k}$ dané problematice postupně všechny, rozdělovala žáky do dvojic na základě losu apod.

\section{„Ten kolektiv vlastně fungoval} dohromady, že si říkali mezi sebou co můžou, čím můžou argumentovat a vlastně $v$ tu chvíli začali spolupracovat, když ta jedna dívka s chlapcem začali pracovat jako tým, když on chtěl poradit." (rozhovor $s$ pedagožkou)

\subsubsection{SWOT analýza}

SWOT analýza je analýzou silných a slabých stránek analyzovaných jevů. Obvykle se zaměřuje na zlepšování strategií konkrétních projektů, služeb či podniků, využívá se při plánovacích procesech a rozhodování o volbě konkrétních strategií či přijímání rozhodnutí, týkajících se často oblastí marketingu a podnikání. Název analýzy se odvíjí od počátečních písmen objektů jejích zájmů: strenghts (síly), weaknesses (slabosti), opportunities (příležitosti) a threats (hrozby). Analýza má pomoci zhodnotit silné a slabé stránky daného programu, marketingové strategie nebo jiné analyzované situace a zároveň identifikovat vhodné př́iležitosti a hrozby s nimi související. ${ }^{19}$ Swot analýza tak může sloužit jako dobrý evaluační nástroj i jako prostředek inovace a zlepšování zkoumaného jevu, v našem případě edukačního programu. Cílem SWOT analýzy je porozumět zkoumané realitě v jejím celku i v rámci dílčích částí, které se vzájemně ovlivňují. Výsledky SWOT analýzy mohou pomoci k lepšímu formulování cílů a strategií analyzovaných jevů a tak vést $\mathrm{k}$ jejich vylepšování.

Cílem předkládané SWOT analýzy je vyhodnotit silné a slabé stránky analyzovaného programu a s ním související hrozby a př́ležitosti ve snaze diskutovat a vylepšit analyzovaný edukační program a zároveň dalším muzejním pedagogům poskytnout užitečné podněty vztahující se $\mathrm{k}$ přípravě a realizaci muzejně edukačních programů obecně. Výsledky SWOT analýzy shrnuje Tab. č. 1 , z níž je patrné, že silné stránky programu nad těmi slabými výrazně dominují. Podrobnější komentář tabulky je součástí výzkumné zprávy.

\section{DISKUZE VÝZKUMNÝCH ZJIŠTĚNÍ}

Kladem edukačního programu je jeho zaměřenost na každodenní život návštěvníků. Ta se projevovala nejen $\mathrm{v}$ rámci navázání tématu programu na každodenní život návštěvníků (život na vesnici versus ve městě), ale také $\mathrm{v}$ tom, že se program zaměřoval na rozvoj pro každodenní život potřebných kompetencí (především kompetencí komunikačních) a na rozvoj vztahů

19 Srov. JANEČKOVÁ, Lidmila a Miroslava VAŠTÍKOVÁ. Marketing služeb. Praha: Grada, 2000, s. 74; POPESCU, Florin a Cezar SCARLAT. Limits of swot analysis and their impact on decisions in early warning systems. SEA Practical Application of Science, 2015, roč. III, č. 1 (7), s. 467-472. ve třídě. Dále v tom, že program využíval prvky konstruktivistických teorií učení, které se projevovaly především ve snaze pedagožky rozvíjet kritické myšlení žáků, což se zrcadlilo především $\mathrm{v}$ rámci nastolování diskutabilních témat a jejich promýšlení a následném argumentování a diskuzi. Důležité bylo také to, že pedagožka žákům př̀edkládala témata určené $\mathrm{k}$ úvaze, spíše než že by jim sdělovala výsledné úhly pohledu na danou problematiku. Kromě toho pedagožka pracovala s dosavadními znalostmi a zkušenostmi žáků. Jako klad konkrétního programu se jeví také fakt, že do jednotlivých aktivit se zapojovali nejen žáci, ale také jejich učitel, který se tak stal součástí jejich muzejní zkušenosti. Kladně je hodnocen také nadšený a angažovaný přístup pedagožky $\mathrm{k}$ tvorbě a realizaci edukačního programu a v neposlední řadě také promyšlená práce pedagožky s prostředím muzea.

Analýza ukázala, že v rámci edukačního procesu hrálo prostředí muzea důležitou roli. Prostor, v němž se edukace odehrávala (místnost s expozicí), vymezoval možnost pohybu žáků a díky svému rozčlenění do několika zón (odpočinková zóna, prostor s osou, zákoutí expozice) žákům umožňoval korigovat míru vlastního zapojení se do konkrétních aktivit. S prostorem souvisela také nutnost uzpůsobení prostředí pro edukaci a to přizpůsobením osvětlení, teploty a eliminací rušivých prvků. Právě v místnosti nacházející se projektor se ukázal jako rizikový faktor, nebot̉ některé žáky rozptyloval a odváděl jejich pozornost od edukačních aktivit. Naopak přínosným vybavením muzea se ukázaly být podložky na sezení a koberec, díky kterému vznikla odpočinková zóna i fyzicky komfortní prostor pro diskuzi. 


\section{Silné stránky}

- situovanost muzea ve větším městě

- dobrá dopravní dostupnost

- vytvoření programu s ohledem na potřeby konkrétní třídy

- znalost třídního kolektivu

- dlouhodobá spolupráce se školou a školní třídou

- flexibilita v reakcích na změny a potřeby návštěvníků

- souvislost $s$ každodenním životem návštěvníků

- možnost zohlednění rámcově vzdělávacích programů

- kurikulární přesah

- zohlednění aktuálních pedagogických trendů, cílů a témat

souvisejících se současnou globalizující se společnosti

- snaha o rozvoj komunikačních dovedností žáků

- využívání RWCT metod

- využívání prvků konstruktivistických teorií učení

- otevírání diskutabilních témat

- práce se stávajícími znalostmi žáků

- kulturně podnětné prostředí

- pohyb v prostoru

- vhodné vybavení (podložky k sezení, koberce...)

- logické řazení aktivit a jejich reflexe

- práce s kolektivem

- aktivní zapojení učitele žáků do aktivit programu

- angažovaný a nadšený muzejní pedagog

- chybějící práce s muzeáliemi

- v expozici chybějící explicitně přítomný chronologický narativ

- malá míra poskytování nových informací

\section{Slabé stránky}

- rušivé prvky v prostoru (projektor)

- chybějící práce s muzeáliemi

- v expozici chybějící explicitně přítomný chronologický narativ

- malá míra poskytování nových informací
Př́ležitosti

- získávání zájmu škol o edukační programy díky dlouhodobé spolupráci s nimi

- vzrůstající společenský zájem o muzejně edukační aktivity

- malá konkurence obdobných programů v okolí
Hrozby

- různorodý kolektiv žáků

- náročnost přípravy edukačního programu

- riziko nezájmu škol o muzejně edukační program

- riziko nezájmu učitelů o užší spolupráci s muzeem

- cena

- doprava do muzea, nutnost opustit prostory školy

Tab. č. 1: SWOT analýza edukačního programu „Argumentace“

Diskutabilní stránkou programu byla jeho volná návaznost na expozici muzea. Právě chybějící práce s exponáty a tak i celkové upozadění muzeality $\mathrm{v}$ edukačním programu bylo zařazeno mezi slabé stránky programu. Více než na práci s exponáty se program orientoval na téma expozice, v rámci kterého se odehrávaly aktivity směřující $\mathrm{k}$ rozvoji specifických kompetencí žáků. Skutečnost, že byl edukační program jen volně svázán s muzejními sbírkami a tedy s muzeálií, staví program mimo klasický proud muzejně edukačních programů. Od těch se obvykle očekává, že právě muzeálie budou jejich ústředním bodem. Upozadění muzeálií je ale v tomto případě potřeba vnímat kontextuálně. Tedy uvědomit si, že byl analyzovaný program součástí širšího celku edukačních aktivit, jejichž běžnou součástí práce s exponáty byla. Právě díky tomu, že byl program součástí takového celku, si mohla pedagožka dovolit se od práce s exponáty více odklonit, aniž by tím vyvrátila potenciál $\mathrm{v}$ muzeu přítomné muzeality. Ta navíc podle pedagožky na žáky pưsobí již svou bezprostřední přítomností v prostoru, ve kterém se edukace odehrává a vytváří tak z učení se v muzeu specifickou edukační realitu. A právě přítomnost muzeality se z pohledu pedagožky zdá být výhodou, kterou muzejní edukace oproti výuce $v$ běžné trrídě přináší. V kontextu analyzovaného programu tak zůstává téma ojedinělého odklonění se od muzeality jako nástroje edukace spíše otázkou do diskuze, než zásadní námitkou. Jaký je edukační efekt muzeality $\mathrm{v}$ případech, kdy muzejní pedagog explicitně nepracuje se samotnými exponáty, by přitom mohl být zajímavým tématem pro jeden $\mathrm{z}$ dalších výzkumů.

Dalším důležitým prvkem pojícím se se specifickým prostředím muzea se ukázala být nutnost stanovení pravidel chování. Ta v programu vycházela ze dvou základních premis: za prvé je nutné chránit sbírky, a proto chování návštěvníků nesmí expozici poškozovat (v muzeu se neběhá ani nesahá na exponáty); za druhé je žádoucí, aby se v muzeu všichni cítili dobře, k čemuž má napomoci slušné chování žáků a jejich vzájemný respekt. 
Další silnou stránkou programu byla úzká a dlouhodobá spolupráce pedagožky s konkrétní školní tř́idou. Důležitost spolupráce muzea se školou není žádnou novinkou. Na tom, že má muzeum potenciál školní výuku efektivně doplnit díky využívání odlišných vzdělávacích metod a forem, jejichž cílem je všestranný rozvoj poznání, kultivace osobnosti návštěvníka a rozvoj jeho hodnotové orientace i mezilidských vztahů, se shodují mnozí představitelé muzejní pedagogiky. ${ }^{20}$ Aby byly tyto snahy muzea úspěšné, je důležité, aby muzeum své návštěvníky, jejich život i potřeby a zájmy znalo. $S$ pochopením potřeb a specifik konkrétních školních tříd přitom může muzejnímu pedagogovi pomoci spolupráce s učitelem, který dokáže specifikovat, s jakými cíli, potřebami a požadavky žáci do muzea přicházejí i dlouhodobá práce s konkrétní skupinou žáků a jejich postupné poznávání. $\mathrm{V}$ analyzovaném programu právě díky dlouhodobé spolupráci s tř́inním učitelem a díky znalosti třídy mohla pedagožka formulovat hlavní cíle programu a s ním pojící se pro žáky aktuální a přínosné téma.

Vyhodnocovat příležitosti a hrozby plynoucí pro edukační program $\mathrm{z}$ vnějšího prostředí bylo $\mathrm{v}$ rámci analýzy nejproblematičtější, nebot $\mathrm{v}$ rámci videostudie a rozhovoru bylo $\mathrm{k}$ této problematice získáno jen málo informací. Pro další fungování programu se jako zásadní jeví hrozba toho, že o program nebudou mít místní školy zájem. Na druhou stranu je možné doufat, že v rámci

20 Srov. Hein in SAVICKE, Jolita a Palmira JUCEVICIENE. Educating Students in Museums: Possibilities for Forming Personal Learning Environments. Social Sciences, 2012, roč. 4, č. 78 s. 76; MORRIS, Estelle a Martha SPURRIER. Museums and Schools: Nurturing an indispensable relationship. In BELLAMY Kate a Carey OPPENHEIM (eds.). Learning to Live: Museums, young people and education. London: Institute for Public Policy Research and National Museum Directors' Conference, 2009, s. 58-66. vzrůstajícího zájmu veřejnosti o muzejní edukaci v dnešní době bude růst i zájem škol o edukační programy muzea. To samozřejmě závisí i na schopnostech muzea informovat školy o své nabídce a o její zajímavosti pro konkrétní školy. Kladným rysem, který může hrát v rámci využívání muzejních edukačních programů do budoucna významnou roli, je ochota pedagožky zohledňovat charakteristiky a potřeby konkrétních návštěvníků muzea a s ohledem na ně programy flexibilně upravovat, stejně jako fakt, že Slezské zemské muzeum je velkým muzeem nacházejícím se ve městě s vlastní sítí škol. Jako rizikový se pak jeví faktor náročnosti př́ípravy edukačních programů šitých na míru potřebám různorodých školních tříd. Pro školy zase může být odrazující cena programu, nebo nutnost opustit kvůli programu prostředí školy, absolvovat komplikace spojené $s$ přesunem žáků do muzea nebo s časovým narušením vlastní výuky. Naopak jako př́ležitost podílející se na zvyšování poptávky po muzejně edukačních programech se jeví možnost učitelů využívat takových edukačních programů, které budou odpovídat konkrétním potřebám školních vzdělávacích programů. Myšleny tím ale nejsou jen edukační programy navazující na obsah školního učiva, ale také programy zaměřující se na rozvoj specifických kompetencí žáků, jejichž potřebnost rozvoje je zakotvena $\mathrm{v}$ rámcově vzdělávacích programech.

\section{ZÁVĚR}

Videostudie jsou dnes stále častěji využívaným výzkumným prostředkem pedagogických výzkumů zabývajících se analýzou edukační reality. Své místo a přínos přitom mohou mít také ve výzkumu muzejněpedagogickém, ve kterém se mohou zabývat širokou škálou zkoumaných fenoménů.
Videostudie mohou pomoci zkoumanou realitu nejen lépe pochopit a přispět tak $\mathrm{k}$ rozšíření teoretického zázemí zkoumané problematiky, ale také se ji mohou díky získaným analytickým výsledkům pokusit následně v praxi vylepšovat a inovovat. Muzejním pedagogům jakožto i dalším realizátorům muzejně edukačních aktivit mohou videostudie přinést zajímavá zjištění i poskytnout zpětnou vazbu. Ta je o to zajímavější, že analýzu provádí do edukačního procesu osobnostně nezaangažovaný výzkumník (nikoli muzejní pedagog, který je realizátorem edukačního procesu), který může přinést emocionálně neutrální a objektivní vhled do zkoumané reality. Tematický záběr videostudií je široký, a pokud ji provádí zkušený výzkumník, je možné prostřednictvím videostudie zkoumat nejrůznější fenomény. Výzkumný zájem se tedy nemusí obracet jen ke klasickým tématům souvisejícími s formami výuky, jejím obsahem či didaktickým aspektem. Pozornost může být věnována i jiným fenoménům, které s muzejní edukací souvisejí, jakými jsou např̀ prostředí muzea, které proces edukace ovlivňuje apod. Široký tematický záběr videostudií je tak pro muzejněpedagogický výzkum výhodou, nebot on sám je orientován na řešení nejrůznějších problémů a zodpovídání rozmanitých otázek.

Analyzovaný edukační program Slezského zemského muzea byl součástí pilotní verze edukačního cyklu, který pedagožka absolvovala s vybranou školní třídou poprvé. Do budoucna by se měl stát součástí stálé nabídky muzea a celý cyklus včetně konkrétního analyzovaného programu bude nabízen dalším školním třídám. Předkládaná videostudie tak v praxi demonstruje, že se může podílet na akčním výzkumu, nebot analýza programu v tomto konkrétním případě bude sloužit 
pedagožce jako př́nosná zpětná vazba a výsledky analýzy budou využity pro další zkvalitnění analyzovaného programu, který je sám o sobě analýzou vnímán jako hodnotný a přínosný edukační počin.

\section{POUŽITÉ ZDROJE:}

DOLEJŠKOVÁ, Petra. Tajemství muzea pedagogicky konstruktivismus a postupy programu RWCT v muzejně-pedagogické praxi určené žákům základních škol. Muzeum: Muzejní a vlastivědná práce, 2011, roč. 49, č. 2, s. 24-29. ISSN $1803-$ $-0386$.

FALK, John H., Lynn D. DIERKING and Marianna ADAMS. Living in a Learning Society: Museums and Free-choice Learning. In MACDONALD, Sharon. A Companion to Museum Studies. Malden, MA: Blackwell Publishing, 2006, s. 323339. ISBN 978-1-4051-0839-3.

JANEČKOVÁ, Lidmila a Miroslava VAŠTíKOVÁ. Marketing služeb. Praha: Grada, 2000. ISBN 80-7169-995-0.

JANÍKOVÁ, Marcela. Interakce a komunikace ve výuce: výzkumné oblasti, přistupy a metody. In JANÍKOVÁ, Marcela, Kateřina VLČKOVÁ a kol. Výzkum výuky: tematické oblasti, výzkumné př́stupy a metody. Brno: Paido, 2009, s. 45-62. ISBN 978-80-7315-180-5.

MACLEOD, Suzanne (ed.). Reshaping Museum Space: Architecture, Design, Exhibitions. London, New York: Routledge, 2005. ISBN 978-0-415-34344-2.

MORRIS, Estelle a Martha SPURRIER. Museums and Schools: Nurturing an indispensable relationship. In BELLAMY Kate a Carey OPPENHEIM (eds.). Learning to Live: Museums, young people and education. London: Institute for Public Policy Research and National Museum Directors' Conference, 2009, s. 58-66. ISBN 978-1-86030-324-1.

POPESCU, Florin a Cezar SCARLAT. Limits of swot analysis and their impact on decisions in early warning systems. SEA - Practical Application of Science,
2015, roč. III, č. 1 (7), s. 467-472. ISSN 2360-2554.

SAVICKE, Jolita a Palmira JUCEVICIENE.

Educating Students in Museums:

Possibilities for Forming Personal

Learning Environments. Social Sciences, 2012, roč. 4, č. 78, s. 75-83. ISSN 2076-0760 .

Slezské zemské muzeum v Opavě [online]. [cit. 2017-01-22]. Dostupný z www: $<$ http://www.szm.cz>.

STRÁNSKÝ, Zbyněk Z. Archeologie a muzeologie. Brno: Masarykova univerzita, 2005. ISBN 80-210-3861-6.

ŠOBÁŇOVÁ, Petra. Muzejní edukace. Olomouc: Univerzita Palackého v Olomouci, 2012. ISBN 978-80-244-3003-4.

Videostudie v pedagogickém výzkumu. Brno: Paido, 2011. ISBN 978-80-7315-222-2.

WORTS, Douglas. Extending the Frame: Forging a New Partnership with the Public. In PEARCE, Susan. Art in Museums. London: The Athlone Press, 1995, s. 164-191. ISBN 978-0-48590005-7.

ZOUNEK, Jiří a Klára ŠEĎOVÁ. Jak zkoumat ict v každodenní práci učitele aneb videostudie jako kvalitativní metoda. ORBIS SCHOLAE, 2008, roč. 2 , č. 1, s. 137-148. ISSN 1802-4637.

\section{VERONIKA KOLAŘíKOVÁ}

Katedra sociální pedagogiky, Pedagogická fakulta,

Masarykova univerzita, Brno, Česká republika

kolarikova.veronika@mail.muni.cz

\section{Veronika Kolaříková je}

absolventkou magisterských

studií oboru sociologie na Fakultě sociálních studií Masarykovy univerzity a oboru sociální pedagogika na Pedagogické fakultě Masarykovy univerzity. V současnosti se její odborný zájem orientuje především na problematiku muzejní edukace $s$ užším zaměřením na tematiku národní identity a její konstrukce.

Veronika Kolaříková completed her master's degree in sociology at the Faculty of Social Studies at Masaryk University and a master's degree in social education at the Faculty of Education, Masaryk University. Currently her research interests are mainly focused on issues of museum education with a narrower focus on the topic of national identity and its construction. 